\title{
Conceptual Model of Evaluation and Acceptance of E-Learning in Vocational Education
}

\author{
Ni Kadek Dessy Hariyanti ${ }^{1}$ \\ Bussiness Administration \\ Politeknik Negeri Bali \\ Bali, Indonesia \\ ${ }^{1}$ dessyhariyanti@pnb.ac.id
}

\author{
Ida Ayu Dwi Giriantari ${ }^{2}$, Linawati ${ }^{3}$ \\ Electrical Enginering \\ Universitas Udayana \\ Bali, Indonesia \\ 2dayugiriantari@unud.ac.id, ${ }^{3}$ linawati@unud.ac.id
}

\begin{abstract}
One of the keys to successful implementation of information technology within an organization is the willingness to accept technology among users. An evaluation process needs to be done to know the success and acceptance of a technology. An E-learning information system has been used since 2016 for the learning and teaching activities in the Bali State Polytechnic. Therefore it is important for management to know how users appreciate in using E-Learning. This study forms a conceptual modeling for the evaluation of success and acceptance of the Elsystem. The model was built with the integration of the UTAUT model, the SI DeLone and McLean Success model and the HOTFit model. The methodology used is the literature review, an overview of existing models and identifies to produce factors that affect the success and acceptance of a technology. Result of research got 3 main factor in conceptual model proposed. The human factor consist of variable of performance expectation, business expectation, social influence and influence of work environment. The technological factors consist of variable quality information, service quality and system quality. The organizational factors consist of conditions of facilities, organizational support, leadership support and organizational environment.
\end{abstract}

Keywords- E-Learning; UTAUT; SI DeLone and McLean Success model; HOT-Fit

\section{INTRODUCTION}

E-learning is one of the implementation of information and communication technology in the field of education. Currently e-learning has become a necessity for academics, that lecturers, students and educational institutions already have sufficient facilities and infrastructure to implement information technology in the learning process. Changes in the paradigm of learning strategies from teacher-centered to student-centered encourage academics to use e-learning as one of the learning methods. The use of e-learning is expected to motivate the improvement of the quality of learning and teaching materials, the quality of student activities and independence, as well as communication between lecturers and students and between the students. E-learning can also be used to overcome the limitations of classrooms and obstacles to distance and time, in the implementation of teaching and learning activities.
Bali State Polytechnic (PNB) is one of the state education institutions consisting of 6 departments and 15 study programs. PNB is an institution providing vocational education. This means that in carrying out lectures, it is not justified if all is done online. E-Learning in PNB is carried out in a blended learning manner, which is a combination of face to face and distance learning, with a maximum provision of $60 \%$ offline and $40 \%$ online. The offline teaching and learning process is filled with practice and assignments in the laboratory. While the online teaching and learning process accommodates remote assignments, quizzes, and also discussions in the form of chat.

E-Learning Development and Implementation at PNB was implemented in 2009 on Moodle (Modular Object Oriented Dynamic Learning Environment). The use of e-learning in PNB was still relatively new at that time. As a new innovation, the adoption process is very vulnerable to rejection. In the 2016 PNB blue print, it is illustrated that the e-learning application is one of the priority applications that must be developed. Furthermore, on the recommendation of the management, it was rebuilt based on the Digital Learning Now Framework. Elearning for this distance learning method can be accessed via kuliah.pnb.ac.id. The use of this technology is in accordance with PNB's first mission, which is to organize vocational education that can be accessed equally for the community. So it is deemed necessary to implement e-learning for supporting the mission.

The implementation has been going on for 2 years, for that it is necessary to analyze the application and acceptance of this technology to users, especially the lecturers. One of the initial keys to the successful implementation of information and communication technology in an organization is the willingness to accept the technology among users. The attitude and behavior of users to be able to receive and utilize elearning in learning process is determined by various factors. Acceptance and adoption of technology can be influenced by many things including user perceptions and the intention to use the system. This study will analyze the application of elearning on vocational learning in PNB, using the combined model of SI Deleon \& McLean, HOT Fit, and UTAUT (Mohamadali, 2010). It is expected that the results of this study 
will produce an evaluation model of e-learning technology acceptance in vocational education.

\section{METHOD}

\section{A. Evaluation Model of Technology Adoption}

Evaluation of acceptance, success and suitability are jointly examined in an integrated model developed by Utomo (2018). This research proposes a new framework for evaluating user acceptance of E-learning technology at the University. The research proposes an integration evaluation model of several models namely the success model of SI DeLone and McLean, Technology Acceptance Model (TAM), acceptance of UTAUT, suitability of HOT Fit, Evaluation Model Of Success And Acceptance Of ELearning, and MELSS with modifications that can evaluate and measure according to the above needs with modifications adapted to the characteristics of the success of e-learning at the university. Utomo's research is limited to modeling, only the implementation of the model has not been proven in the measurement of acceptability and the success of the system. While this study uses 3 model interrogations, namely the model of SI DeLone and McLean's success, the suitability of HOT Fit and the UTAUT model

Mohamadali's research (2010) proposed a new framework for evaluating user acceptance of software technology in the health service sector. The study proposes an integrated evaluation model, namely the integration of the UTAUT user acceptance model, the success model of SI DeLone and McLean, and the Task Technology Fit (TTF) model. Mohamadali's research (2010) became the basis of Yuliasari's (2014) and Ramayasa (2015) research which analyzed the factors that influence auditors in using the Regional Government Financial Statement Examination Application System (SiAP LKPD) and its implications for auditor performance. The integration model also used by Puspita (2013) examines the acceptance of hospital management information systems with a combination of UTAUT-TFF models. The research model used is the integration model of the UTAUT acceptance model, the success of SI DeLone and McLean, and the suitability of HOT Fit.

Tan (2013) implemented UTAUT to get factors that influence the use of English E-Learning Websites in Taiwan. Tan also discussed the comparison of various methods of evaluating the success of the SI and reviewing their respective shortcomings and strengths. While Wang (2003) studied the use of Elearning in companies, using the development of the DeLeno \& Mclean method called ELSS (Elearning e-learning systems success). In determining several indicators of variable measurement, this study refers to Tan (2013) and Wang (2003), which are modified and adapted to the PNB campus environment Using the adoption theory of innovation approach, which combines the UTAUT, HOT Fit models and the success of SI Deeno \& McLean, This study intends to examine the determinants of acceptance and utilization of e-learning by users in the PNB environment. This research is expected to be able to assist the leadership in developing policies and utilizing e-learning in PNB.

\section{B. Integrated PNB E-Learning Model Evaluation}

Mohamadali and Garibaldi (2010) proposed an integrated evaluation model by combining three SI theories, namely the UTAUT model, the SI DeLone and McLean success model, and the HotFit model. The UTAUT model and SI success using the dependent variable are almost the same, namely the intention to use a system, where the UTAUT model uses the term "behavioral intention" while the SI success model uses the term "intention to use" or "use". However, each model has different independent variables. In the UTAUT model, behavioral intentions are determined by performance expectations, business expectations, and social influences. In the success model, the intention to use is determined by the quality of information, system quality, and service quality

The UTAUT model only examines the effect of constructs on behavioral intentions, not yet connecting to the results of use. The success model has linked usage with its impact. According to Mohamadali and Garibaldi (2010), SI's success or failure is very dependent on the suitability between the three levels, namely human beings, technology organizations. The incorporation of independent factors in the two models and the addition of the human-organization-technology suitability model produce an integrated model that provides a better representation of the determinants of intention.

The success models of SI DeLone and McLean are very good for assessing the success of the system based on information quality, system quality and quality of SI services that affect user satisfaction and net benefits from SI usage (DeLone, 2003). However, this model has not been able to evaluate SI related to factors that influence users to accept and use SI.

The suitability model of HOT Fit (Yusof, 2006) is the development of the success model of SI DeLone and McLean and classifies its independent variables into three dimensions, namely human, organization and technology. The HOT Fit model can assess the success of information systems and acceptance of SI usage and assess the suitability between human-technology-organizations in the implementation of SI. Lack of HOT Fit models is that variables in the human dimension have not explained further the factors that influence user acceptance to use SI.

The integrated evaluation model (Mohamadali, 2010) combines the independent variables of the UTAUT acceptance model and the SI DeLone and McLean success model and the HotFit suitability model. In addition, the integrated evaluation model classifies the independent variables into three main factors, namely human, organizational and technological factors. This model is believed to be able to describe the success and acceptance of SI based on usage intentions, user satisfaction, and net benefits of SI usage. This model has assessed the suitability of human-organization-technology towards the implementation of SI, but the organizational factors in this model have not fully described the influence of the organization on the use of SI, thus requiring further research to complement organizational factors to be more representative. 
To evaluate the success and acceptance of e-learning SI in $\mathrm{PNB}$, an evaluation model is needed that can illustrate the factors that influence the success of SI and user acceptance of SI. Evaluation models are also needed that have assessment indicators about the intention to use and user satisfaction in using SI, including the variables that influence it according to the characteristics of PNB users (lecturers), as well as the impact of SI usage in the form of net benefits obtained. In addition, a model that can measure the suitability between humans (lecturers), technology (SI elearning) and organizations (PNB leaders) is needed.

The evaluation model of SI e-learning success and acceptance proposed in this study is an integration model of the UTAUT acceptance model, SI DeLone and McLean success model and the suitability of HOT Fit with modifications that can evaluate and measure in accordance with the above requirements with customized modifications to PNB characteristics.

\section{CONCEPTUAL Model OF E-LEARNING ACCEPTANCE}

Based on the results of the abstraction and synthesis of the theory from the literature review, this study will analyze the adoption of E-Learning technology using an integrated model of the HOT-Fit model, UTAUT, and successful models of SI DeLone and McLean. The conceptual model of E-Learning system acceptance can be described as Figure 1.

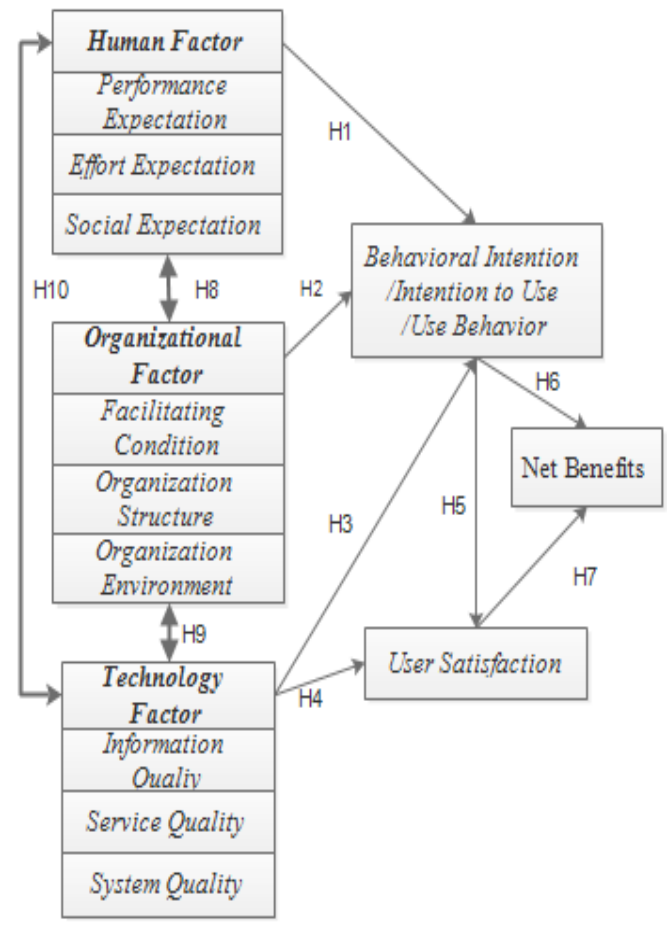

Fig. 1. The proposed integration model (Mohamadali, 2010)

From the literature review and previous research, according to the conceptual framework above the research hypothesis can be determined, namely:
H1 Human factors influence the Intention of Using ELearning

H2 Human factors influence the Intention of Using ELearning

H3 Human factors affect the Intention of Using E-Learning

H4 Technology Factors affect E-Learning User Satisfaction

H5 Intention to Use E-Learning has an effect on User Satisfaction

H6 Intention to Use E-Learning affects the Net Benefits

H7 User satisfaction affects the Net Benefits

H8 Human Factors have a relationship of conformity with the Organization

H9 Organizational Factors have a relationship of conformity with Technology

H10 Human Factors have a relationship of conformity with technology

TABLE I. VARIABLE DESCRIPTION

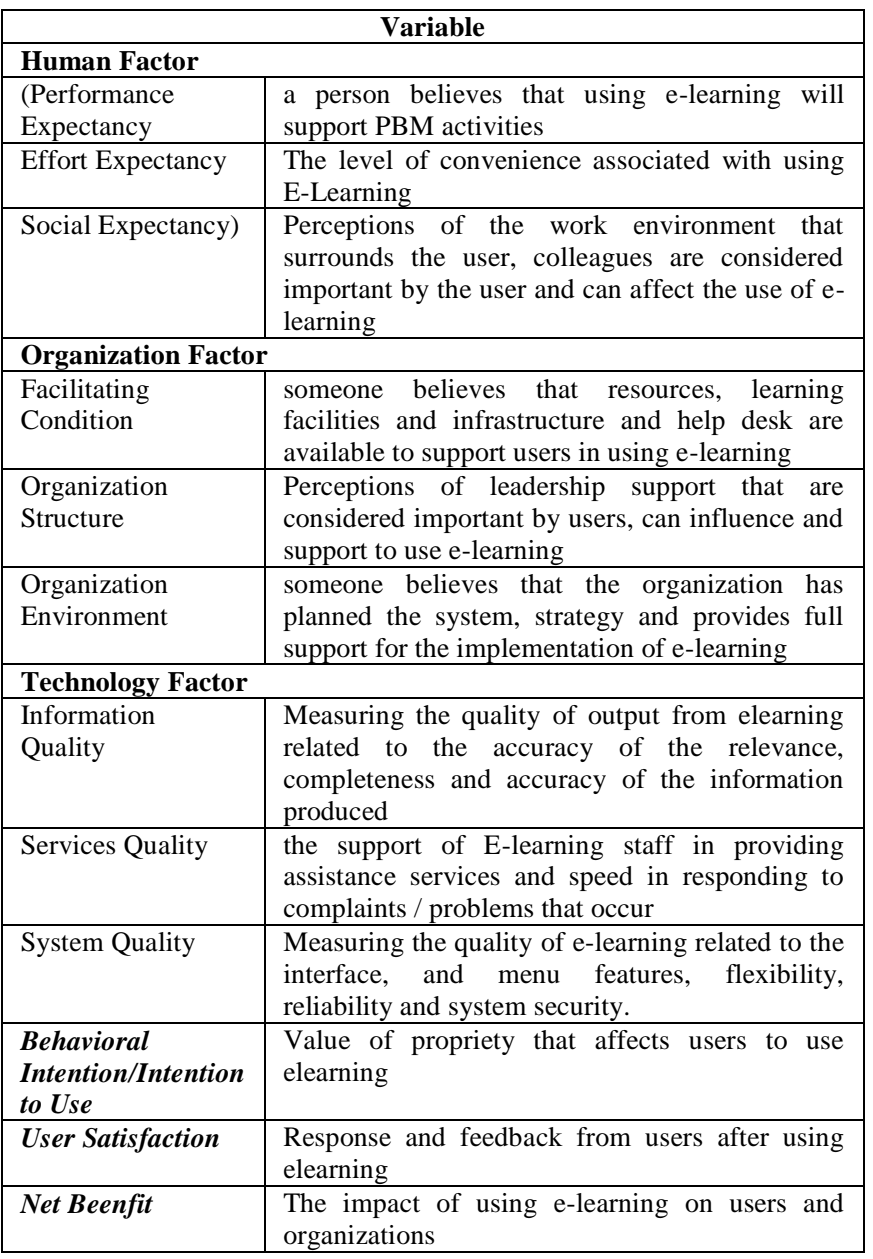

\section{CONCLUSION}

The proposed conceptual model of e-learning acceptance is a modification of the HOT Fit model concept, UTAUT and McDeleon success models that are adapted to user characteristics in the PNB environment. Variables and indicators that support the analysis are selected through 
literature review which refers to important factors in the successful acceptance and adoption of e-learning technology.

Result of research got 3 main factors in conceptual proposed model. The human factor consists of variables of performance expectation, business expectation, social influence and influence of work environment. The technological factors consist of variable quality information, service quality and system quality. The organizational factors consist of conditions of facilities, organizational support, leadership support and organizational environment. Conceptual e-learning acceptance model produced can provide an overview of indicators that must be considered and can be developed for further research.

\section{ACKNOWLEDGEMENT}

The authors would like to thank to research center and community service of Politeknik Negeri Bali for the financing of this research.

\section{REFERENCES}

[1] W. DeLone and E.R. McLean, "Information System Success : The Quest for Dependent Variable," Inform System Res., vol. 3, no. 1, pp. 60-95, 1992.

[2] W. DeLone, and E.R. McLean, "The DeLone and McLean Model of Information System Success: A Ten Year Update,” J. of Manag. Inform. Systems, no. 19, vol. 4, pp 9-30, 2003.

[3] W. DeLone and E.R. McLean, "Measuring e-Commerce Success L Applying DeLone \& McLean Information Systems Success Model," Int. J. Electronic Commerce, vol. 9, no.1, pp 31-47, 2004.

[4] K.C. Dewi and I.P.M. Astawa, "Perencanaan Strategis E-Learning Politeknik Negeri Bali Menggunakan Ward And Peppard Framework, Matrix,” J. Manajemen Teknologi dan Informatika, vol. 6, no. 2, pp. 7479, 2017.

[5] Mohamadali and J.M. Garibaldi, "A Novel Evaluation Model of User Acceptance of Software Technology in Healthcare Sector," Proceed. [International Conference on Health Informatics, 2010].

[6] H. Pamugar, "Model Evaluasi Kesuksesan dan Penerimaan Sistem Informasi E-Learning pada Lembaga Diklat Pemerintah," Sci. J. of Inform., vol. 1, no. 1, pp. 13-28, 2014
[7] P. Novianti, "Analisis Penerapan Sistem Informasi Manajemen Rumah Sakit Menggunakan Metode UTAUT dan TTF," J. Nasional Teknik Elektro dan Teknologi Informasi, vol. 2, no. 4, pp. 225-232, 2013.

[8] I.P. Ramayasa, "Evaluation Model of Success and Acceptance of ELearning," J. Theoretical App. Inform. Tech., vol.82, no.3, pp. 462-469, 2015 .

[9] S. Erimalata, "Pendekatan Hot-Fit Framework Dalam Generalized Structural Component Analysis pada Sistem Informasi Manajemen Barang Milik Daerah: Sebuah Pengujian Efek Resiprokal Jurnal Akuntansi dan Investasi," vol. 17, no. 2, pp. 141-157, 2016

[10] I.K Suja, I.W.C. Winetra, and K.C. Dewi, "Pembuatan Blueprint Tata Kelola Politeknik Negeri Bali,” J. Logic, vol. 16, no.1, pp. 20-24, 2016.

[11] P.J.B. Tan, "Applying the UTAUT to Understand Factors Affecting the Use of English E-Learning Websites in Taiwan," Sage J., vol. 1, no. 1, pp. 1-12, 2013.

[12] A.P. Utomo, N. Mariana., R.S.A. Rejeki, "Model Evaluasi Integrasi Kesuksesan Dan Penerimaan Sistem Informasi E-Learning Universitas," Ikraith-Informatika, vol. 2, no. 1, pp. 94-101, 2018.

[13] V. Venkatesh, M.G. Morris, G.B. Davis and F.D. Davis, "User Acceptance of Information Technology: Toward A Unified View," MIS Quarterly, vol. 27, no. 3, pp. 425-478, 2003.

[14] Y.S. Wang, H.Y. Wang, and D.Y. Shee, A Measuring e-learning systems success in an organizational context: Scale development and validation Computers in Human Behavior," Comp. Human Behav., vol 23, no. 4, pp. 1792-1808, 2007

[15] E. Yuliasari, "Analisis Faktor Determinan Penggunaan Sistem Aplikasi Pemeriksaan Laporan Keuangan dan Implikasinya," J. Nasional Teknik Elektro dan Teknologi Informasi, vol. 03, no. 2, pp. 83-89, 2014,

[16] M.M. Yusof, R.J. Paul, and L.K. Stergioulas, "Towards a Framework for Health Information Systems Evaluation. Proceed. IEEE [the 39th Hawaii International Conference on System Sciences 2006].

[17] M.M. Yusof, J. Kuljis, A. Papazafeiropoulou, L.K. Stergioulas, "An Evaluation Framework for Health Information Systems: Human, Organization, and Technology-Fit Factors (HOT-Fit)," Int. J. Med. Inform., vol. 77, no. 6, pp. 386-398, 2008

[18] M.M. Yusof, "Hot-Fit Evaluation Framework: Validation Using Case Studies and Qualitative Sytemic Review in Health Information Systems Evaluation Adoption," Prooced. [the European Conference on Information Management and Evaluation, 8-9 September, Mono: Italy. 2011].

[19] M.M. Yusof and Y.A.Y. Yusuf, "Evaluating E-Government System Effectiveness Using an Integrated Socio-Technical and Fit Approach.," Inform. Tech. J., vol. 12, no. 5, pp 894-906, 2013. 